SOSIOLIUM

\title{
IMPLEMENTASI PENDIDIKAN KARAKTER DALAM PEMBELAJARAN IPS DI MADRASAH TSANAWIYAH MUHAMMADIYAH SRUMBUNG KABUPATEN MAGELANG
}

\author{
Putri Suryaningsih, Rudi Salam ${ }^{凶}$
}

Prodi Pendidikan IPS, Fakultas Ilmu Sosial, Universitas Negeri Semarang, Indonesia.

\section{Info Artikel \\ Sejarah Artikel: \\ Disubmit: Juli 2020 \\ Direvisi: Agustus 2020 \\ Diterima: September 2020

Keywords:
Character Education;
Sosial Studies
Leraning. \\ Keywords: \\ Sosial Studies \\ Leraning.

\begin{abstract}
Abstrak
MTs Muhammadiyah Srumbung adalah sekolah yang kental dengan ajaran agama Islam. Pendidikan karakakter disampaikan melalui dua tahap yaitu budaya kelas dan budaya lingkungan sekolah. Artikel ini bertujuan untuk 1) Mengetahui implementasi pendidikan karakter dalam pembelajaran IPS, 2) Mengetahui respon peserta didik dengan adanya implementasi pendidikan karakter dalam pembelajaran IPS, 3) Mengetahui faktor penghambat dan pendukung implementasi pendidikan karakter dalam pembelajaran IPS. Hasil penelitian menemukan bahwa 1) Implementasi pendidikan karakter dalam pembelajaran IPS melalui budaya kelas dan lingkungan sekolah. Pada budaya kelas melalui tahap perencanaan, proses pembelajaran, dan evaluasi, sedangkan budaya sekolah melalui kegiatan pembiasaan dan ekstrakurikuler di sekolah, 2) Respon peserta didik terhadap adanya implementasi pendidikan karakter adalah positif, 3) Faktor penghambat dan pendukung adalah sekolah (guru dan peserta didik), orangtua dan lingkungan.
\end{abstract}

\begin{abstract}
MTs Muhammadiyah Srumbung is a school with strong Islamic teachings. Character education is delivered through two stages, namely the classroom culture and the culture of the school environment. This article aims to 1) Know the implementation of character education in social studies learning, 2) Know the students' responses to the implementation of character education in social studies learning, 3) Know the inhibiting and supporting factors for the implementation of character education in social studies learning. The results of the study found that 1) Implementation of character education in social studies learning through classroom culture and school environment. Class culture goes through the planning, learning and evaluation process, while school culture is through habituation and extracurricular activities in schools, 2) The response of students to the implementation of character education is positive, 3) The inhibiting and supporting factors are school (teachers and students), parents and the environment.
\end{abstract}

\footnotetext{
Alamat korespondensi:

Gedung C1, Lantai 1, FIS Unnes

Kampus Sekaran, Gunungpati, Semarang, 50229

Email: rudisalam@mail.unnes.ac.id
} 


\section{PENDAHULUAN}

Pendidikan adalah tempat untuk menuntut ilmu dan proses dimana seseorang akan mengembangkan potensi, keahlian dan bakat minatnya melalui dunia pendidikan. Tidak hanya bidang akademik saja tetapi juga spiritual, sosial humaniora, dan pengendalian emosional seseorang. Pendidikan merupakan pilar tegaknya suatu bangsa, melalui pendidikan suatu bangsa akan tegak mampu menjaga martabatnya. Pendidikan merupakan salah satu upaya untuk mengembalikan fungsi manusia menjadi manusia agar terhindar dari berbagai bentuk penindasan, kebodohan sampai kepada ketertinggalan, sehingga pendidikan sangat berperan penting dalam membentuk sebuah kepribadian seseorang dan intelektual seseorang yang mana dapat dijadikan pedoman atau bekal untuk bersaing di dunia kerja maupun kehidupan. Hal ini sesuai dengan fungsi Pendidikan nasional dalam Undang-Undang Nomor 20 Tahun 2003 berbunyi "Pendidikan nasional berfungsi mengembangkan kemampuan dan membentuk watak serta peradaban bangsa yang bermartabat dalam rangka mencerdaskan kehidupan bangsa, bertujuan untuk berkembangnya potensi peserta didik agar menjadi manusia yang beriman dan bertakwa kepada Tuhan Yang Maha Esa, berakhlak mulia, sehat, berilmu, cakap, kreatif, mandiri, dan menjadi warga negara yang demokratis serta bertanggungjawab".

Koesoema (2010) mengemukakan bahwa pendidikan merupakan proses sosial yang bertujuan membantu peserta didik selaku generasi muda agar mengerti dengan baik tatanan sosial dalam masyarakat, mengerti pola perilaku, norma, sopan santun dan tata krama yang dihargai dalam masyarakat. Peserta didik pada masanya akan terjun kedalam masyarakat, mereka tidak mengalami kesulitan dalam pergaulan, dalam rangka pengembangan kehidupan profesional mereka sebagai orangorang dewasa dan bertanggung jawab. Fungsi pendidikan nasional adalah mengantarkan generasi muda sebagai seseorang yang mengembangkan kemampuannya sehingga terbentuk watak dan peradaban bangsa yang bermartabat. Semuanya itu bermuara pada upaya mencerdaskan kehidupan bangsa dan menciptakan generasi muda yang berkualitas dan dapat bersaing di kancah internasional.

Sebuah pendidikan akan berjalan baik apabila proses belajar tersebut juga baik dengan diimbangi mutu pendidikan yang berkualitas, sehingga akan tercapai tujuan-tujuan pendidikan yang diharapkan. Guru sebagai fasilitator harus benar-benar berkualitas karena guru kunci dari apa yang akan peserta didik dapatkan dari proses belajar, selain mutu pendidikan mutu siswa pun juga sangat penting dalam proses pencapaian pendidikan ini, karena itu mutu dari seorang siswa harus ditingkatkan. Tugas pendidik yang berperan sebagai aktor utama dalam mengelola pembelajaran, tidak hanya memberikan pembelajaran di kelas tetapi juga memberikan sebuah motivasi dan penanaman sebuah nilanilai karakter. Guru akan bisa sepenuhnya berada disamping peserta didiknya ketika kegiatan belajar mengajar berlangsung didalamnya guru sepenuhnya berbeperan sebagai seorang pendidik dan juga orangtua yang berusaha mendidik dan mencerdaskan anaknya. Ketika guru sedang memberikan pelajaran di kelas harus selalu disisipkan niai-nilai karakter didalamnya supaya anak akan terbiasa dan secara tidak langsung akan tercermin karakter yang baik dalam dirinya yang kemudian diimplementasikan dalam kehidupan seharihari.

Menurut Suyanto (2010) dalam Agus Wibowo (2012) karakter adalah cara berfikir dan berperilaku yang menjadi ciri khas tiap individu untuk hidup dan bekerja sama, baik dalam lingkup keluarga, masyarakat bangsa dan negara, individu yang berkarakter baik adalah individu yang bisa membuat keputusan dan siap mempertanggungjawabkan tiap akibat dari keputusan yang dibuat. Sementara pendidikan karakter adalah pendidikan budi pekerti plus yaitu yang melibatkan aspek pengetahuan (cognitive), perasaan (feeling) dan tindakan (action). Tanpa ketiga aspek ini maka karakter tidak akan akan efektif.

Pendidikan karakter merupakan upayaupaya yang dirancang dan dilaksanakan secara sistematis untuk membantu peserta didik memahami nilai-nilai perilaku manusia yang berhubungan dengan Tuhan, diri sendiri, sesama 
manusia, lingkungan dan kebangsaan yang terwujud dalam pikiran, sikap, perasaan, perkataan dan perbuatan berdasarkan normanorma agama, hukum, tata krama, budaya dan adat istiadat. Pendidikan karakter ini mencakup banyak hal tidak hanya sikap saja akan tetapi mengenai kebangsaan dan adat istiadat yang mana hal tersebut juga identik dengan Indonesia yang beragam kebudayaan. Sehingga sangat wajib untuk generasi muda melestarikan, menjaga dan meningkatkan kebudayaan milik Indonesia. Pendidikan karakter ini terus berlanjut tidak akan berhenti karena kita selalu berhubungan dengan sebuah karakter setiap melakukan sebuah tindakan dan juga untuk menyiapkan para generasi muda yang berkualitas baik.

Pemberian pendidikan karakter bangsa di sekolah, dapat diberikan dengan cara pertama berdiri sendiri sebagai suatu mata pelajaran khusus pendidikan karakter. Kedua, pendidikan karakter bangsa diberikan secara terintegrasi dalam mata pelajaran PKn, mata pelajaran IPS, pendidikan agama, dan mata pelajaran lain yang relevan. Ketiga, pendidikan karakter bangsa terintegrasi ke dalam kegiatan ekstrakurikuler sekolah yang ada. Menumbuhkan jiwa yang berkarakter dapat dilakukan melewati pendidikan formal dan informal yang dapat dirancang dan diintegrasikan dalam rencana pembelajaran.

Trianto (2010) mengemukakan IPS merupakan integrasi dari berbagai cabang ilmuilmu sosial, seperti sosiologi, sejarah, geografi, ekonomi, politik, hukum dan budaya yang dirumuskan atas dasar kenyataan dan fenomena sosial dan diwujudkan dalam suatu pendekatan inter- disiplinerd dari aspek dan cabang ilmu-ilmu sosial. IPS merupakan bagian dari kurikulum sekolah yang diturunkan dari isi materi cabangcabang ilmu sosial. IPS juga didalam mengaji masalah atau fenomena-fenomena terkait kehidupan manusia dan lingkungan sekitar. Lewat mata pelajaran ini diharapakan penanaman pendidikan karakter peserta didik dapat berkembang dengan baik karena didalam materi pelajaran IPS ini berhubugan erat dengan sosial yang mana itu merupakan kehidupan manusia yang saling berkaitan satu sama lain dan manusia adalah makhluk sosial yang saling membutuhkan satu sama lain.

Sekolah yang terdapat di daerah kecamatan Srumbung cukup banyak dan tersebar dimasing-masing desa sehingga mudah ditemui sekolah di kecamatan Srumbung. Terdapat sebanyak 54 sekolah dengan jenjang pendidikan SD/MI dan SMP/MTs. Terdapat 25 sekolah swasta dengan rincian $16 \mathrm{MI}, 2 \mathrm{MTs}$, 4 SMP, 2 SD dan 1 SMA. Kemudian sebanyak 29 sekolah negeri dengan rincian $27 \mathrm{SD}$ dan 2 SMP (Kemendikbud, 12 Mei 2020).

MTs Muhammadiyah Srumbung merupakan sekolah yang berada dibawah naungan yayasan Muhammadiyah. Sekolah ini merupakan sekolah dengan cirri khusus adanya pemberian materi pelajaran Islam dan kemuhammadiyahan. Oleh karena itu, pembudayaan agama yang dilakukan didalam sekolah tersebut memiliki kekhususan yang beda dari sekolah pada umumnya terutama sekolah di Kecamatan Srumbung. Adanya pembudayaan yang bersifat religi dan juga dengan pembiasaan yang dilakukan setiap hari di sekolah. Melalui kegiatan-kegiatan yang dapat menumbuhkan karakter dalam diri peserta didik, seperti salat duha dan zuhur berjama'ah, baca tulis AlQur'an, kultum. Kegiatan upacara, baris berbaris dan kegiatan ekstrakurikuler seperti tapak suci, hizbul wathan, rebana, angklung merupakan kegiatan yang bermanfaat di sekolah ini seharusnya dapat membuat peserta didik memiliki karakter yang baik akan tetapi pada kenyataanya belum sepenuhnya memiliki dan menerapkan kepada kehidupan sehari-hari. Peserta didik masih melanggar peraturan sekolah seperti membolos, terlambat sekolah, berpakaian tidak rapi, membuang sampah sembarangan, tidak menjaga kebersihan kelas, mencontek, menunda salat berjamaah, ramai ketika pembelajaran berlangsung dan berani kepada guru di sekolah. Hal ini menunjukan bahwa peserta didik belum memiliki karakter dalam dirinya. Terdapat hukuman atas perbuatan melanggar sekolah hal ini supaya peserta didik jera dan tidak mengulangi kesalahan tersebut. Akan tetapi, peserta didik masih ada yang melanggar peraturan sekolah. 
Berdasarkan latar belakang tersebut peneliti berfokus mengetahui 1) Implementasi pendidikan karakter dalam pembelajaran IPS di Madrasah Tsanawiyah Muhammadiyah Srumbung, 2) Respon peserta ddik adanya implementasi pendidikan karakter, 3) Faktor penghambat dan pendukung implementasi pendidikan karakter dalam pembelajaran IPS di Madrasah Tsanawiyah Muhammadiyah Srumbung Kabupaten Magelang.

\section{METODE}

Penelitian ini menggunakan metode penelitian kualitatif. Bogdan dan Taylor dalam Moloeng (2007) mendefinisikan penelitian kualitatif sebagai prosedur penelitian yang menghasilkan data deskriptif berupa kata-kata tertulis atau lisan dari orang-orang dan perilaku yang diamati dari fenomena yang terjadi. Tujuan dari penelitian ini adalah untuk mendeskripsikan implementasi pendidikan karakter dalam pembelajaran IPS di Madrasah Tsanawiyah Muhammadiyah Srumbung Kabupaten Magelang. Lokasi penelitian mengambil lokasi di MTs Muhammadiyah Srumbung.

Fokus penelitian ini yaitu penggambaran proses implementasi pendidikan karakter dalam pembelajaran IPS, respon peserta didik dan faktor penghambat dan pendukung implementasi pendidikan karakter. Sumber data dalam penelitian ini diperoleh melalui sumber data primer dan sekunder. Data primer diperoleh melalui observasi dan wawancara yang dilakukan dengan informan. Sumber data sekunder berasal dari foto dokumentasi diperoleh dari kegiatan pembelajaran di kelas. Teknik pengumpulan data dilakukan dengan cara observasi, wawancara dan dokumentasi. Wawancara dilakukan secara langsung dengan informan yaitu guru IPS, kepala sekolah dan peserta didik kelas VIII. Uji validitas data yang digunakan dalam penelitian ini adalah triangulasi sumber. Uji keabsahan data yang digunakan dalam penelitian ini adalah model analisis interaktif Miles Huberman yaitu pengumpulan data, reduksi data, penyajian data dan penarikan kesimpulan/Verifikasi.

\section{HASIL DAN PEMBAHASAN}

MTs Muhammadiyah Srumbung berada dekat dengan Jalan raya desa tetapi jauh dari keramaian jalan besar utama. Sekitar MTs Muhammadiyah Srumbung terdapat satu tempat foto copy dan satu toko toserba di sebrang jalan. Batas-batas MTs Muhammadiyah Srumbung terdiri dari: sebelah Utara berbatasan dengan rumah penduduk sekitar Desa Gejayan dan masjid, sebelah Timur berbatasan dengan persawahan, sebelah Barat berbatasan dengan persawahan, toko dan rumah penduduk dan sebelah Selatan berbatasan dengan persawahan.

\section{Profil MTs Muhammadiyah Srumbung}

MTs Muhammadiyah Srumbung adalah sekolah swasta yang berada di Jalan Gulon Soka Km 5 Gejayan Polengan Srumbung Kabupaten Magelang. MTs Muhammadiyah Srumbung dipimpin oleh Bapak Endro Purwanto, S.Pd dan telah terakreditasi A. Visi MTs Muhammadiyah Srumbung adalah Terwujudnya peserta didik yang Intelek, Santun, Beriman, Mandiri, Unggul, dan Usaha (INSAN BERMUTU). Guru dan karyawan di MTs Muhammadiyah Srumbung berjumlah 19 orang. Peserta didik berjumlah sebanyak 164 anak dengan rincian kelas VII sebanyak 37 anak, kelas VIII sebanyak 57 dan kelas IX sebanyak 70 amak. Sarana dan prasarana cukup memadai dengan rincian yaitu 1) ruang kepala sekolah, 2) ruang guru, 3) ruang BK, 4) ruang tamu, 5) 8 ruang kelas, 6) laboratorium IPA, 7) laboratorium komputer, 8) perpustakaan, 9) UKS, 10) mushola, 11) lapangan, 12) tempat parkir, 13) kamar mandi \& toilet, 14) kantin, 15) dapur dan 16) gudang. Kegiatan ekstrakurikuler yang ada di MTs Muhammadiyah Srumbung antara lain drumband, rebana/hadroh, koor, angklung, tapak suci dan HW (Hizbul Wathan).

\section{Implementasi Pendidikan Karakter dalam Pembelajaran IPS melalui Budaya Kelas}

\section{Perencanaan}

Perencanaan pendidikan karakter dalam proses pembelajaran Ilmu Pengetahuan Sosial yang pertama adalah penyusunan pembelajaran yaitu pembuatan silabus dan rencana perangkat pembelajaran (RPP). Sesuai dengan peraturan 
pemerintah terkait kurikulum 2013 yang sudah diterapkan di sekolah-sekolah yang mana menekankan pada pendidikan karakter peserta didik. Harapannya peserta didik memiliki akademik yang bagus dan karakter yang baik sesuai dengan harapan tujuan pendidikan nasional. Kurikulum yang diterapkan di MTs adalah kurikulum 2013. Masing-masing guru menyusun RPP dan menyesuaikan kondisi masing-masing kemudian melakukan perubahan tetapi tetap sesuai pada RPP yang telah disusun.

RPP yang disusun oleh Ibu Suharyanti, S.Pd yang terlampir pada lampiran 5 halaman 161 tercantum beberapa nilai karakter didalamnya mulai dari pembukaan, kegiatan inti dan penutup. Hasil dari penelitian menunjukan bahwa guru IPS menyusun RPP dalam materi Kedatangan Bangsa-bangsa Eropa ke Indonesia menampilkan nilai karakter dalam RPP yakni religius, sopan santun, kedisiplinan, kesungguhan, ketelitian, rasa ingin tahu, kreatifitas, berfikir kritis, rasa percaya diri, dan rasa tanggung jawab dan mandiri. Perencanaan pendidikan karakter dalam pembelajaran Ilmu Pengetahuan Sosial di MTs Muhammadiyah Srumbung dan kesesuaian ketika pelaksanaan dapat dikatakan sudah sesuai dengan RPP yang disusun. Hanya ada sedikit perubahan ketika pelaksanaan hal ini dikarenakan disesuaikan dengan situasi dan kondisi peserta didik supaya tujuan pembelajaran yang di harapkan dapat tercapai dengan baik.

\section{Pelaksanaan}

Proses pelaksanaan pembelajaran terdapat tiga tahap yakni kegiatan pendahuluan, inti dan penutup. Kegiatan pendahuluan guru mengucapkan salam. Mempersiapkan peserta didik untuk mengikuti pembelajaran seperti meminta anak duduk dengan rapi dan sopan. Kemudian setelah semua siap menerima pembelajaran menyiapkan untuk berdo'a bersama. Kemudian membaca doa harian dan surat-surat pendek dilanjut dengan baca tulis $\mathrm{Al}$ qur'an (BTQ) hal ini merupakan wujud dari karakter religius. Hal ini sesuai dengan pernyataan Ibu Suharyanti bahwa ketika sudah masuk kelas berdo'a kemudian dilanjut dengan membaca do'a harian dan surat pendek. Nah itu sudah ada jadwalnya mbak. Minggu pertama do'a apa dan surat apa. Setelah itu ada BTQ setiap hari selasa, rabu dan kamis. BTQ dipimpin oleh wali kelas dan didampingi guru lain. Dikarenakan sistemnya satu anak disimak oleh guru khusus untuk iqra'. Sedangkan yang Al Qur'an diminta untuk simaan dengan teman yang lain kemudian mengisi buku pegangan siswa.

Kemudian memeriksa kehadiran peserta didik serta memeriksa peserta didik membawa buku paket IPS atau tidak hal itu menjadi salah satu kegiatan rutin yang guru tanyakan kepada peserta didik. Memeriksa kehadiran merupakan wujud dari rasa peduli dan empati. Kemudian wujud dari dan tanggung jawab peserta didik dengan hal sederhana yakni membawa buku paket IPS. Senada dengan pendapat Ibu Suharyanti mengatakan bahwa dalam masalah membawa buku paket. Setiap kali saya masuk ke kelas saya bertanya satu persatu kepada anak membawa buku atau tidak. Jika sampai tiga kali anak tidak membawa buku saya meminta pihak perpustakaan untuk mengambil buku tersebut. Jika buku hilang atau rusak anak tersebut harus mengganti berupa uang ataupun buku.

Setelah memeriksa kehadiran peserta didik guru memberikan motivasi untuk mendorong peserta didik lebih bersemangat dalam pembelajaran. Seperti yang Ibu Suharyanti lakukan ketika disela-sela pembelajaran memberikan nasehat atau motivasi kepada peserta didik seperti cara bersikap di kelas cara duduk, cara berbicara atau perilaku peserta didik. Hal ini juga sesuai dengan pendapat Bapak Endro Purwanto bahwa guru selalu memberikan motivasi kepada peserta didik di setiap pembelajaran. Senada dengan pendapat Ibu Juli Astuti bahwa ketiaka pembelajaran pemberian motivasi menjadi hal yang selalu dilakukan oleh guru diawal sebelum pemberian materi diberikan. Motivasi yang dikaitkan dengan kehidupan sehari-hari yang nantinya akan dialami oleh peserta didik dimasa depan. Kemudian selalu menasehati jika peserta didik berperilaku kurang sopan. senada dengan pendapat Agus Prianggodo bahwa informan mengatakan guru memberikan nasihat dan motivasi supaya semua peserta didik dapat bersikap disiplin dan berperilaku baik. 
Kemudian guru memberikan rangsangan kepada peserta didik sebelum masuk ke materi. Hal ini diharapkan peserta didik sudah siap menerima pembelajaran yang akan disampaikan guru dengan memberikan pertanyaan-pertanyaan umum dan sederhana kepada peserta didik. Secara tidak langsung guru memberikan kebebasan peserta didik untuk lebih mengeksplor apa yang diketahui dan berani merangsang untuk berpendapat. Menurut pendapat Raya Khairunisa kebebasan yang diberikan oleh guru adalah ketika berpendapat dan bertanya. Memberikan kebebasan peserta didik untuk mengemukakan apa yang ada difikiran peserta didik. Sama halnya dengan pendapat Khoirunisa mengatakan bahwa kebebasan yang ada adalah ketika sedang mengerjakan tugas dan peserta didik diberi kebebasan untuk mencari di buku paket.

Kegiatan Inti, Guru menjelaskan materi terkait Kedatangan Bangsa-bangsa Eropa ke Indonesia. Ketika guru sedang menjelaskan peserta didik beraneka ragam ada yang memperhatikan dengan serius, ada yang tidur, ada yang berbicara dengan temannya, ada yang melamun, ada juga yang diam saja. Hal ini memang wajar ketika proses pembelajaran berlangsung. Akan tetapi menurut Ibu Suharyanti peserta didik masih tergolong aktif dan dapat diajak bekerjasama dengan baik. Berdasarkan hasil observasi peneliti ketika mengikuti pembelajaran di kelas VIII A dan B semua peserta didik tergolong aktif hanya satu dua yang sedikit kurang memperhatikan. Ibu Suharyanti menerapkan cara satu jam digunakan untuk menerangkan materi kemudian satu jam selanjutnya digunakan untuk mengerjakan tugas.

Hal ini dimaksudkan supaya peserta didik mau belajar dan membaca buku. Hal tersebut sudah merupakan pembiasaan yang dilakukan guru untuk menanamkan karakter gemar membaca kepada peserta didik. Ketika memberikan tugas Ibu Suharyanti tidak lantas membiarkan peserta didik bebas tanpa mengawasi. Ketika anak ada tugas baik di kelas maupun di luar kelas selalu mengawasi peserta didik supaya tetap mengerjakan dengan baik. Sama halnya dengan pendapat Ibu Juli Astuti bahwa guru selalu mengawasi peserta didiknya.
Melihat setiap gerak gerik peserta didik di kelas, memperhatikan ketika mengerjakan tugas. Hal tersebut termasuk dalam sikap peduli, empati dan perhatian seorang guru kepada peserta didiknya.

Implementasi pendidikan karakter yang ditanamkan Ibu Suharyanti salah satunya melalui kegiatan marketing atau berjualan. Kegiatan marketing diatas dilakukan setiap seminggu satu kali. Kegiatan baru diterapkan di kelas VIII A putri. Kegiatan ini terdiri dari 2 orang satu kelompoknya dan masih dalam lingkup lingkungan kelas dan sekolah penjualannya. Barang yang diperjual belikan berupa makanan. Makanan tersebut bisa dibuat sendiri, membeli yang sudah jadi ataupun dibuatkan orangtua. Ibu Suharyanti tidak membatasi peserta didik dalam memperoleh barang jualan tersebut. Hasil dari kegiatan berjualan ini peserta didik diminta untuk membuat laporan. Laporan yang sederhana yang menunjukan hasil dari penjualan peserta didik yang berisi nama kelompok, nama barang, jumlah barang, harga/biji, dan hasilnya untung atau rugi. Menurut Ibu Suharyanti selama kegiatan berjualan ini peserta didik sangat semangat dan belum pernah ada yang tidak berjualan dapat dikatakan kegiatan ini berjalaan lancar.

Implementasi pendidikan karakter yang ditanamkan kepada peserta didik di kelas VIII B putra masih berupa pemberian tugas-tugas. Pemberian tugas individu selain kemandirian terdapat juga nilai tanggung jawab dan kerja keras peserta didik dalam mengerjakan tugastugas. Ketika peserta didik mengerjakan dengan sendiri tugasnya dan tidak mencontek serta mengandalkan temannya berarti sudah tertanam dalam dirinya karakter mandiri. Karena belum semua peserta didik memiliki karakter mandiri didalam dirinya sehingga memerlukan cara-cara sederhana ataupun umum untuk menanamkan karakter tersebut. Kemudian berdasarkan hasil observasi peneliti senada dengan pernyataan Ibu Suharyanti bahwa peserta didik ketika mengerjakan tugas, mengerjakan dengan baik dan berusaha sendiri untuk dapat menjawab soal-soal yang ada dengan cara mencari dari buku paket IPS. Suasana ketika peserta didik mengerjakan soal 
cukup nyaman dan kondusif sehingga peserta didik dapat berkonsentrasi dengan baik.

Didukung dengan pernyataan Bapak Endro Purwanto bahwa sekitar $85 \%$ dapat dikatakan bahwa peserta didik mengerjakan tugas dengan baik. Sama halnya dengan pendapat Ibu Juli Astuti bahwa anak-anak mengerjakan tugas dengan baik. Pada kelas VIII A dan B berjalan baik dan anak mengerjakan tugas dengan baik. Satu kelas dengan yang lainnya memiliki ciri khas yang berbeda sehingga guru harus dapat memahami karakteristik anak dan kelas. Sehingga cara mengajar berbeda disesuaikan dengan karakter peserta didik dan kemampuannya. Supaya semua peserta didik dapat mengerjakan tugastugas dengan baik. Pemberian tugas dilakukan oleh semua guru karena tugas-tugas diperlukan untuk mengasah kemampuan peserta didik dan mencari nilai dari peserta didik. Peserta didik juga merasakan bahwa pemberian tugas kepada mereka merupakan sebuah penanaman karakter mandiri karena ketika mengerjakan tugas mereka harus mengerjakan tugas dengan mandiri.

Membiasakan peserta didik membaca dan mengerjakan akan membuat peserta didik secara tidak langsung jika diberi tugas dia akan membaca buku yang ada dan berusaha untuk mengerjakan dan memecahkan masalah yang dihadapi. Kemudian jika memang dirasa sulit peserta didik akan bertanya kepada guru dan guru harus siap sedia jika peserta didik bertanya terkait kesulitan yang dialami. Setiap peserta didik pasti memiliki permasalahan masingmasing disini peran guru dalam membantu menyelesaikan permasalahan peserta didik. Terdapat peserta didik yang mampu memecahkan masalahnya sendiri tetapi juga ada yang membutuhkan bantuan orang lain terutama seorang guru. Bermacam-macam cara peserta didik dalam mengatasi masalah atau kesulitan yang sedang dihadapi. Masalah yang dihadapi peserta didik bermacam-macam misalkan kesulitan dalam belajar, dalam memahami pelajaran, kesulitan mengerjakan tugas yang sulit ataupun masalah diluar pembelajaran.

Membantu kesulitan peserta didik sampai masalah tersebut selesai sehingga tidak berlarut-larut dan menganggu kegiatan pembelajaran sehingga kegiatan pembelajaran dapat berjalan lancar. Pendapat Ibu Suharyanti sesuai dengan pendapat peserta didik yang mengatakan bahwa guru membantu jika peserta didik mengalami kesulitan atau masalah. Menurut hasil analisis peneliti menunjukan bahwa peserta didik rata-rata mengatakan bahwa dalam pemecahan masalah atau kesulitan guru selalu membantu memecahkannya. Menurut Raya Khairunisa mengatakan bahwa Bapak/Ibu guru di sekolah selalu siap sedia untuk membantu semua peserta didik ketika sedang mempunyai masalah. Kemudian menurut Pramuyada mengatakan bahwa Bapak/Ibu guru selalu menolong dalam kesulitan apapun yang dialami peserta didik. Senada dengan pendapat Bapak Endro Purwanto bahwa guru selalu membantu kesulitan siswa melalui kesiswaan dan BK. Cara membantu permasalahan juga disesuaikan dengan masalah yang masing-masing yang dihadapi peserta didik. ini merupakan wujud dari karakter peduli terhadap sesama.

Kegiatan penutup, Kegiatan penutup diisi dengan memberikan kesimpulan dan dan refleksi kepada peserta didik. Setelah selesai peserta didik selalu mengucapkan hamdalah dan menutup pembelajaran dengan berdo'a bersama. Hal ini termasuk wujud dari karakter religius. Bagi kelas putri setelah pembelajaran peserta didik wajib bersalaman dengan guru perempuan sebaliknya kelas putra bersalaman dengan guru laki-laki.

\section{Evaluasi}

Evaluasi yang dilakukan oleh guru adalah dengan mengamati sikap dan perilaku peserta didik ketika berkegiatan ataupun ketika diberikan tugas-tugas. Evaluasi berupa tugastugas harian, ulangan harian, pengamatan tugas proyek. Setiap satu KD memberikan tugas, kemudian beberapa $\mathrm{KD}$ dengan ulangan harian. Kemudian dengan penilaian harian bersama, ulangan semester dan UKK. Sehingga guru dapat mengetahui apa saja yang perlu dilakukan perbaharuan dalam sistem belajar tersebut. 


\section{Implementasi Pendidikan Karakter dalam Budaya Sekolah}

Implementasi pendidikan karakter melalui pembiasaan-pembiasaan yang ada di sekolah sebagai budaya sekolah. Budaya yang ada di MTs Muhammadiyah Srumbung antara lain sebagai berikut:

\section{Salat duha dan zuhur berjama'ah}

MTs Muhammadiyah Srumbung selalu mewajibkan peserta didik dan guru untuk melaksanakan salat berjama'ah. Pada jam istirahat pertama sebelum istirahat adalah salat duha berjama'ah. Kemudian di jam istirahat kedua salat zuhur berjama'ah. Hal ini merupakan salah satu pembiasaan untuk menanamkan pendidikan karakter religius kepada peserta didik. Laki-laki dan perempuan salat secara terpisah. Seusai menunaikan salat peserta didik secara giliran akan mengisi kultum (kuliah tujuh menit) didepan. Urutan pengisi kultum sesuai diurutkan mulai dari kelas VII sd IX. Kemudian urutan untuk pengisi kultum sesuai dengan presensi masing-masing kelas. Sehingga semua peserta didik akan mendapatkan giliranya. Laki-laki sesuai dengan urutan laki-laki dan sebaliknya perempuan sesuai urutan yang perempuan. Hal ini merupakan wujud dari implementasi pendidikan karakter yaitu religius.

\section{Bersalaman dengan Bapak/Ibu guru}

Kegiatan pembiasaan yang dilakukan sekolah untuk menanamkan karakter supaya peserta didik bersikap sopan santun kepada orang yang lebih tua dan juga menghormati. Kegiatan bersalaman dengan guru selalu dilaksanakan seusai upacara hari Senin selesai. Sebelum peserta didik meninggalkan lapangan upacara, peserta didik wajib bersalaman dengan Bapak/Ibu guru. Perempuan bersalaman dengan guru perempuan dan sebaliknya laki-laki bersalaman dengan guru laki-laki.

Baris-berbaris

Sebelum memasuki kelas peserta didik wajib baris - berbaris di depan kelas. Dipimpin oleh ketua kelas masing-masing. Hal ini menjadi salah satu pembiasaan yang dilakukan sekolah untuk mendisiplinkan peserta didik. Supaya peserta didik sebelum memasuki ruangan kelas sudah siap untuk belajar.

\section{Upacara}

Kegiatan upacara yang rutin dilaksanakan setiap hari Senin pagi. Semua peserta didik dan guru harus datang tepat waktu untuk mengikuti upacara hari Senin. Karakter yang terwujud dari kegiatan upacara adalah semangat kebangsaan, nasionalisme, cinta tanah air, dan disiplin. Semua peserta upacara harus mengikuti dengan penuh khitmat dan disiplin dengan posisi sempurna.

Sabtu bersih

Kegiatan sabtu bersih yang selalu dilaksanakan MTs Muhammadiyah Srumbung. Semua warga MTs Muhammadiyah Srumbung baik peserta didik maupun guru saling membersihkan lingkungan sekolah. Kegiatan sabtu bersih ini dilakukan pada hari Sabtu satu bulan sekali tepatnya pada minggu ketiga. Lingkungan sekolah dan ruangan kelas dibersihkan secara bersama-sama. Hal ini merupakan salah satu karakter gotong-royong dan peduli lingkungan. Jika lingkungan sekolah dan kelas bersih kegiatan belajar mengajar akan menjadi lebih nyaman dan efektif.

\section{Kegiatan ekstrakurikuler}

Ektsrakurikuler

di MTs

Muhammadiyah Srumbung salah satunya adalah tapak suci, hizbul wathan (HW) dan angklung. Kegiatan tapak suci ini sama halnya dengan ekstra pencak silat. Kegiatan tapak suci dilaksanakan pada hari Kamis sore seusai pulang sekolah. Kegiatan HW dilaksanakan pada hari Sabtu. HW ini sama dengan pramuka bedanya dalam kegiatan HW terdapat mata pelajaran terkait kemuhamadiyahan. Kemudian untuk angklung dilaksanakan pada hari Rabu seusai pulang sekolah. Kegiatan ekstrakurikuler secara tidak langsung juga menjadi tempat untuk menanamkan pendidikan karakter kepada peserta didik. Hal ini bisa dilihat dari ekstrakurikuler tersebut mengajarkan beberapa karakter antara lain disiplin, saling bekerjasama, komunikatif, dan gotong royong.

Kemudian tulisan-tulisan slogan di sekolah juga menjadi salah satu cara menanamkan karakter kepada peserta didik. 
Tulisan pertama berbunyi "Unggul dalam Ilmu Santun dalam Perilaku". Hal ini menunjukan bahwa antara ilmu dan perilaku saling seimbang. Peserta didik harus memilki akademik yang bagus diimbangi dengan karakter yang baik. Peserta didik harus bersikap santun kepada guru-guru di sekolah kepada teman saling menghargai. Tulisan kedua berbunyi "Dilaranng membuang sisa makanan yang berminyak ke kolam". Artinya semua warga MTs Muhammadiyah Srumbung diajak untuk menjaga lingkungan sekolah dan peduli terhadap lingkungan sekolah. Hal ini juga termasuk salah satu perwujudan dari karakter peduli lingkungan. Sehingga lingkungan sekolah menjadi nyaman dan bersih.

\section{Respon Peserta Didik adanya Implementasi Pendidikan Karakter dalam Pembelajaran IPS}

Secara tidak sadar peserta didik diajak oleh guru dalam hal bersikap dan bertindak untuk menumbuhkan karakter dalam diri masing-masing peserta didik. Awalnya respon peserta didik sedikit susah akan tetapi karena telah menjadi sebuah pembiasaan dan rutinitas sehingga melakukan tanpa ada paksaan. Proses pembelajaran berlangsung yang di lakukan anak di dalam kelas beranekaragam antara lain mendengarkan guru, memperhatikan penjelasan guru dan mencoba memahami apa yang dijelaskan oleh guru. Ketika peneliti mengikuti kegiatan pembelajaran di kelas VIII A dan B. Ketika guru masuk awalnya sedikit gaduh dan ramai kemudian ketika guru sudah duduk dan menyiapkan diri anak mulai diam dan kondusif. Ketika guru menjelaskan peserta didik diam memperhatikan, aktif mendengarkan, ada yang ngobrol, dan ada yang tidur. Hal ini sesuai dengan pendapatan yang Ibu Suharyanti katakan. Bahwa memang suasana peserta didik didalam kelas bermacam-macam. Tergantung bagiamana guru dalam mengatur peserta didik supaya tetap memperhatikan ketika pembelajaran sedang berlangsung.

Kemudian saat guru memberikan waktu bertanya peserta didik bertanya satu dua orang bertanya dan apabila tidak ada yang bertanya guru yang bertanya kepada peserta didik. Sehingga suasana aktif dalam kelas tercipta dengan baik dan berjalan lancar. Walaupun yang bertanya hanya orang-orang tertentu saja setidaknya teman yang tidak bertanya ketika ada yang bertanya juga mengetahui jawaban yang tidak diketahui oleh temannya tersebut. Sama halnya dengan pendapat Ibu Juli Astuti bahwa peserta didik harus dipancing terlebih dahulu diberikan waktu dan motivasi untuk bertanya. Sehingga setelah itu peserta didik anak berani bertanya. Senada dengan pernyataan Bapak Endro Purwanto yang mengatakan bahwa ketika diberikan waktu untuk bertanya sebagian aktif bertanya mencoba mengatasi rasa ingin tahunya, ada juga teman yang lain yang tidak bertanya mendengarkan apa yang ditanyakan temannya.

Implementasi pendidikan karakter yang ditanamkan oleh guru adalah salah satunya tadi dengan memberikan tugas baik individu, diskusi maupun kelompok. Tanggapan atau respon peserta didik awalnya sedikit mengeluh tetapi dikerjakan dengan sukarela karena sudah menyadari bahwa itu merupakan tanggungajawab dan kewajiban dia sebagai peserta didik. Peserta didik mengerjakan tugas dengan baik dan juga tenang ketika mengerjakan tugas yang diberikan guru dan ketika waktu sudah habis segera mengumpulkan bahkan ada yang selesai lebih dahulu dari jam yang ditentukan. Berdasarkan hasil peneliti secara keseluruhan jawaban informan adalah mengerjakan tugas dengan baik dan sungguhsungguh. Menurut Raya Khairunisa mengatakan bahwa tugas yang diberikan oleh guru diberikan dikerjakan dengan semampu dan sebisa peserta didik dan baik. Sama halnya dengan pendapat Khoirunisa mengatakan bahwa pekerjaan atau tugas yang diberikan dikerjakan dengan baik dan sampai jam pelajaran habis sehingga peserta didik tetap berada di kelas pada jam pelajaran yang bersangkutan. Sama halnya dengan pendapat Bapak Endro Purwanto bahwa ketika anak diberikan tugas anak mengerjakan dengan baik sekitar $85 \%$. Hal ini menunjukan bahwa peserta didik mengerjakan tugas dengan baik dan bersungguh-sungguh. Menunjukan respon yang baik ketika diberikan tugas.

Respon ketika peserta didi kelas VIII A diajak untuk berjualan sangat baik dan antusias sekali. Hal ini menunjukan bahwa peserta didik 
ketika diajak secara langsung bagaimana cara berjualan, berinteraksi dengan orang banyak, bagaimana cara berbicara dengan orang lain supaya mau membeli dan memunculkan kepercayaan dalam diri. Cara itu dilakukan untuk mempersiapkan peserta didik di masa depan bisa mengembangkan ide yang dimiliki, mengembangkan kreatifitasnya dan dapat membuat sebuah usaha.

Faktor Penghambat dan Pendukung Implementasi Pendidikan Karakter dalam Pembelajaran IPS

\section{Faktor Penghambat}

\section{Kebiasaan peserta didik}

Peserta didik berasal dari SDM yang berbeda sehingga karakter mereka juga bermacam-macam. Hal tersebut juga akan berpengaruh dalam karakter kelas masingmasing, mana kelas yang bisa diatur dan tidak. Sama halnya dengan pendapat peneliti pada saat observasi bahwa kebiasaan atau karakter dari peserta didik dapat memengaruhi bagaimana kelas tersebut apakah kondusif atau tidak. Ketika satu kelas berisi peserta didik yang sulit diatur kondisi kelas tidak berjalan baik dan kondusif sehingga kegiatan belajar mengajar kurang efektif. Peserta didik ramai, tidak memperhatikan bahkan mengganggu kelas disebelahnya. Sedangkan satu kelas berisi peserta didik yang dapat diatur kelas akan lebih kondusif dan efektif ketika pembelajaran berlangsung.

Kesadaran peserta didik mentaati aturan sekolah

Kesadaran peserta didik masih kurang terdapat beberapa pelanggaran yang masih dilakukan dan terjadi. Hal ini menandakan sikap disiplin peserta didik masih kurang. Menurut Nindha Kurniawati mengatakan bahwa pelanggaran yang pernah dilakukan adalah makan di kelas, membiarkan kuku panjang dan tidak membawa buku pelajaran. Kemudian menurut Farida Aurilia mengatakan bahwa pelanggaran yang pernah dilakukan di sekolah adalah tidak memakai kerudung dengan berlogo MTs. Dari pernyataan informan diatas dapat disimpulkan bahwa peserta didik masih banyak yang melanggar peraturan sekolah. Peserta didik belum sepenuhnya mentaati peraturan sekolah, kesadaran untuk mentaati peraturan sekolah masih rendah.

\section{Motivasi peserta didik masih kurang}

Motivasi peserta didik dalam hal jika diberikan tugas oleh guru masih menundanunda tidak langsung dikerjakan. Ketika diberikan tugas oleh guru mengeluh bahkan menawar soal yang akan diberikan.

Orangtua

Ibu Suharyanti mengatakan pengawasan orangtua ketika di rumah sangatlah penting dan harus. Pengawasan belajar peserta didik dirumah sangat penting seperti menanyakan pekerjaan rumah, mengawasi belajar anak, dan mengingatkan untuk keperluan sekolah. Tidak adanya pengawasan dari orangtua sehingga peserta didik memiliki pekerjaan rumah tidak dikerjakan, tidak menjadwal dan lain-lain. Sama halnya dengan pendapat Ibu Juli Astuti bahwa peran orangtua sangat berpengaruh untuk mendukung penananaman karakter. Ketidaksamaan pendidikan di sekolah dan di rumah merupakan salah satu penghambat dalam penanaman karakter kepada peserta didik.

\section{Lingkungan}

Ibu Suharyanti mengatakan lingkungan sangat berpengaruh terutama soal pergaulan. Waktu di rumah lebih banyak daripada sekolah. Kemudian di rumah tidak seperti sekolah yang terdapat peraturan khusus yang didalamnya mengatur segala tingkah laku, sikap dan kegiatan peserta didik.

\section{Faktor Pendukung Peraturan sekolah}

Peraturan kelas maupun sekolah keduanya digunakan untuk mengontrol peserta didik supaya berperilaku baik. Berdasarkan pendapat Raya Khairunisa bahwa peraturan di kelas tidak terlalu ketat. Senada dengan pendapat Eka Kurniasari bahwa peraturan di kelas cukup ketat tetapi tidak menyulitkan peserta didik karena hal tersebut juga untuk mendisiplinkan. Sehingga dapat disimpulkan bahwa aturan kelas terutama dirasa peserta didik ketat sesuai dengan standarnya sehingga tidak membuat peserta didik tertekan. 


\section{Ketegasan guru}

Guru adalah sebuah pandangan atau teladan bagi peserta didiknya sehingga guru harus memberikan contoh yang baik. Menurut peserta didik guru mapel IPS memiliki sifat tegas, baik, disiplin dan penyabar. Sehingga guru tersebut dapat menjadi contoh bagi peserta didik. Hal ini senada dengan pernyataan Bapak Endro Purwanto bahwa guru di Madrasah sudah memiliki karakter yang baik sehingga dapat dijadikan contoh bagi peserta didik.

\section{Orangtua}

Mengimplementasikan karakter terutama karakter kepada peserta didik juga didukung dengan kebiasaan dari orangtua ketika dirumah. Sehingga sejak dari rumah terutama orangtua sudah menanamkan karakter tersebut kepada anak-anaknya. Menurut pernyataan Bapak Endro Purwanto bahwa sekitar 90\% orangtua peserta didik bersifat kooperatif atau dapat diajak bekerjasama dengan sekolah untuk mendukung adanya penanaman pendidikan karakter. Hanya terdapat beberapa orangtua yang terkadang masih sulit diajak bekerjasama. Hal ini senada dengan pendapat Munawarah mengatakan bahwa orangtua selalu mengajarkan hal-hal mandiri seperti menadiri untuk bangun lebih pagi, merapikan tempat tidur. Kemudian menurut Raya Khairunisa mengatakan bahwa orangtua mengajarkan agar dapat melakukan sesuatu hal dengan mandiri seperti mencuci baju sendiri.

\section{PEMBAHASAN}

\section{Implementasi Pendidikan Karakter dalam Pembelajaran IPS \\ Guru mengimplementasikan}

pendidikan karakter dalam budaya kelas melalui tahap perencanaan, proses pembelajaran dan evaluasi. Pada tahap perencanaan implementasi tersebut yaitu Rencana Pelaksanaan Pembelajaran (RPP). RPP merupakan sebuah rancangan pembelajaran yang didalamnya memuat nilai-nilai karakter yang akan dikembangkan oleh guru. Implementasi penanaman karakter di sekolah RPP berfungsi untuk mendorong semua guru agar siap dalam melakukan kegiatan pembelajaran, membentuk kompetensi dan karakter peserta didik. Implementasi pendidikan karakter di sekolah RPP berfungsi untuk mendorong guru agar siap dalam melakukan kegiatan pembelajaran, membentuk kompetensi dan karakter peserta didik. Mulyasa (2018) menyatakan RPP berkarakter berfungsi untuk mengefektifkan proses pembelajaran dan pembentukan karakter peserta didik disesuaikan dengan RPP dan menyiapkan serta mengembangkan bahan ajar yang berwawasan karakter. Menyiapkan bahan ajar dalam implementasi pendidikan karakter merupakan bagian yang penting menentukan tercapainya tujuan pembelajaran. Sehingga guru memiliki panduan atau pedoman dalam mengajar. Tahap pelaksanaan melalui kegiatan pendahuluan, inti dan penutup. Kemudian juga implementasi pendidikan karakter melalui budaya lingkungan sekolah dengan kegiatan pembiasaan dan ekstrakurikuler.

Implementasi pendidikan karakter dalam budaya kelas di MTs Muhammadiyah Srumbung yang dilakukan oleh Ibu Suharyanti yaitu pada perencanaan, pelaksanaan dan evaluasi. Kemudian pada proses pembelajaran meliputi kegiatan pendahuluan, kegiatan inti dan penutup. Ketiga tahap tersebut didalamnya secara tidak langsung mengandung nilai-nilai karakter yang ditanamkan oleh guru dan sekolah. Proses pembentukan karakter menurut Nasirudin (2010) ada tiga tahap yaitu pemahaman, pembiasaan dan keteladanan.

Memberikan pemahaman kepada peserta didik dengan cara yang sederhana dan mudah dimengerti oleh peserta didik. Memberikan apersepsi dengan kehidupan sehari-hari. Memberikan contoh yang ada lingkungan sekitar. Selalu mengajak dan menasehati peserta didik supaya menjadi baik. Apersepsi yang diberikan guru menjadi salah satu pembiasaan diawal pembelajaran. Menanamkan dan membiasakan peserta didik untuk berperilaku baik. Ketika pembelajaran dimulai masingmasing guru memiliki pembiasaan sendirisendiri. Penanaman karakter yang dilakukan oleh Ibu Suharyanti adalah menanyakan buku kepada peserta didik sekaligus mengecek kehadirannya. Pembiasaan adalah sebuah kegiatan yang berulang-ulang dilakukan sehingga menjadi sebuha kebiasaan. 
Pembiasaan yang baik di sekolah akan membentuk anak menjadi berkepribadian baik. Hal ini sesuai dengan tujuan pendidikan karakter menurut Mulyasa (2018) bertujuan untuk meningkatkan mutu proses dan hasil pendidikan yang mengarah pada pembentukan karakter dan akhlak mulia peserta didik secara utuh, terpadu dan seimbang, sesuai dengan standar kompetensi lulusan pada setiap satuan pendidikan.

Kemudian pemberian motivasi dan pengarahan kepada peserta didik merupakan hal wajib yang dilakukan oleh Ibu Suharyanti ketika didalam kelas. Hal ini supaya peserta didik dapat terbiasa bersikap baik dan bertutur kata dengan sopan. Pemberian pengarahan kepada peserta didik ketika dalam kesulitan ataupun sedang mengalami masalah sebagai wujud perhatian, peduli dan empati seorang guru.

Pemberian tugas dan pelatihan yang dilakukan oleh guru adalah salah satu cara pengimplementasian pendidikan karakter. Penugasan dapat berupa individu maupun kelompok sesuai dengan masing-masing guru dan metode yang guru gunakan. Kemudian pelatihan marketing yang dilakukan selain pemberian tugas adalah salah satu cara pengimplementasian pendidikan karakter mandiri, bertanggung jawab. Hal ini dilakukan bertujuan supaya peserta didik memiliki kepercayaan diri, keberanian dalam berkomunikasi dengan orang lain dan menumbuhkan sikap wirausaha peserta didik.

Keteladanan, guru selalu memberikan contoh yang baik, mentaati peraturan dengan masuk kelas tepat waktu, menggunkaan bahasa yang sopan dan sesuai etika, dan berpakain rapi dan bersih. Bersikap tegas, disiplin dan sabar dalam membantu permasalahan yang dialami peserta didik. Hal ini akan dilihat oleh peserta didik dan menjadi teladan yang baik.

\section{Respon Peserta Didik adanya Implementasi Pendidikan Karakter dalam Pembelajaran IPS}

Hasil dari penelitian menunjukan bahwa peserta didik MTs Muhammadiyah Srumbung sudah memiliki karakter dalam dirinya hanya beberapa anak saja yang masih belum memiliki.respon dari peserta didik cukup positif dan diterima dengan baik. Menurut Lickona
(2019) menyebutkan tiga komponen karakter utama yaitu Moral Knowing, Moral feeling dan Moral behaviour. Bahwa karakter yang baik didukung oleh pengetahuan tentang kebaikan, keinginan untuk berbuat baik dan melakukan perbuatan baik. Hal ini perlu agar manusia dapat memahami, merasakan dan mengerjakan hal kebaikan.

Hal ini selaras dengan penanaman karakter yang ada di MTs Muhammadiyah Srumbung. Berawal dari sebuah pembiasaan yang dilakukan terus-menerus sehingga menjadi sebuah kebiasaan dan karakter dalam hati jiwa pesrta didik. Hal ini ditunjukan dengan peserta didik yang mengerjakan tugas yang diberikan oleh guru dengan baik. Tidak mencontek pekerjaan temanya ataupun mengandalkan pekerjaan orang lain. Berusaha sendiri dalam melakukan segala hal yang tampak terlihat sederhana, akan tetapi hal tersebut termasuk karakter mandiri dan bertanggungjawab. Respon ketika diberikan tugas oleh guru cukup diterima baik oleh peserta didik dan cukup baik daya saing dalam belajar peserta didiknya. Kemudian dalam menjalankan pembiasaanpembiasaan yang ada di lingkungan sekolah seperti salat berjama'ah, upacara, kegiatan ekstrakurikuler bahkan sabtu bersih sudah berjalan cukup baik dengan didukung respon postif dari peserta didik. Menunjukan bahwa respon pserta didik terlihat dari tindakan yang dilakukan tersebut.

\section{Faktor Penghambat dan Pendukung Implementasi Pendidikan Karakter dalam Pembelajaran IPS}

Faktor penghambat

Faktor penghambat pelaksanaan pendidikan karakter berasal dari faktor internal dan eksternal. Faktor internal yaitu 1) kebiasaan peserta didik, 2) kesadaran peserta didik mentaati aturan, 3) motivasi peserta didik masih kurang, 4) orangtua. Sedangkan faktor eksternl yaitu berasal dari lingkungan terutama pergaulan.

Faktor pendukung pelaksanaan pendidikan karakter berasal dari 1) perautan sekolah, 2) ketegasan guru dan 3) orangtua. Hal ini menunjukan bahwa secara tidak langsung komponen pendidikan (guru, peserta didik, 
kepala sekolah dan aturan sekolah), orangtua dan lingkungan sangat penting dan saling melengkapi satu sama lain dalam menanamkan pendidikan karakter kepada peserta didik.

Hal ini sesuai dengan pendapat Gunawan (2014) menyebutkan bahwa faktor yang mempengaruhi pembentukan karakter, akhlak, moral, budi pekerti dan etika manusia dibagi menjadi dua yaitu faktor intern dan ekstern. Faktor intern antara lain 1) insting/naluri, 2) adat/kebiasan, 3) kehendak/kemauan, 4) suara batin/suara hati, 5) keturunan. Sedangkan faktor ekstern antara lain 1) pendidikan dan 2) lingkungan.

\section{SIMPULAN}

Implementasi pendidikan karakter dalam pembelajaran IPS di MTs Muhammadiyah Srumbung melalui budaya kelas dilaksanakan melalui tahap perencanaan, proses pembelajaran/pelaksanaan, dan evaluasi. Tahap perencanaanya adalah pada Rencana Perangkat Pembelajaran (RPP) yang didalamnya memuat nilai-nilai karakter yang akan akan dikembangkan oleh guru. Kemudian pada tahap proses pembelajaran/pelaksanaan dilakukan pada kegiatan pendahuluan, inti dan penutup. Tahap pendahuluan yang dilakukan guru adalah berdo'a, mengkondisikan lingkungan kelas dan peserta didik,mengecek kehadiran peserta didik, kemudian pemberian motivasi. Tahap inti guru menyisipkan nilainilai karakter yang sesuai dengan materi selama peserta didik melakukan pembelajaran dan penugasan/pelatihan terkait materi IPS. Penugasan berupa tugas individu maupun kelompok. Tahap penutup guru memberikan kesimpulan dan refleksi diakhir pembelajaran. Evaluasi yang dilakukan guru IPS adalah dengan tugas-tugas yang diberikan untuk mengamati sikap dan perilaku peserta didik.

Implementasi pendidikan karakter melalui budaya sekolah adalah dengan pembiasaan-pembiasaan yang ada di lingkungan sekolah seperti salat duha dan zuhur berjama'ah disertai kultum, bersalaman dengan guru, baris-berbaris, upacara hari Senin, Sabtu bersih, dan kegiatan ekstrakurikuler di MTs Muhammadiyah Srumbung.

Adapun respon peserta didik ketika diberikan pembiasaan maupun tugas-tugas oleh guru diterima cukup baik. Hanya satu dua anak yang belum memiliki karakter kemandirian dalam dirinya. Hal ini dibuktikan dengan ketika diberikan tugas mengerjakan dengan baik tanpa mencontek pekerjan teman, mengerjakan dengan sungguh-sungguh, dan memiliki daya saing yang cukup ketika mengerjakan tugas.

Faktor yang sangat berpengaruh dalam implementasi pendidikan karakter baik faktor pendukung dan penghambat adalah sekolah (peserta didik dan guru), orangtua dan lingkungan terutama pergaulan anak. Ketiga komponen yang saling berperan penting dalam terbentuknya karakter peserta didik.

\section{DAFTAR PUSTAKA}

Gunawan, Heri. 2014. Pendidikan Karakter. Bandung: Alfabeta.

Koesoema Albertus, Doni. 2010. Pendidikan Karakter. Roma: Fakultas Ilmu Pendidikan Universitas Kepausan Salesian.

Lickona, T. (2019). Education for Character: How Our School Can Teach Respect and Responsibility. New York: Bantam Books.

Mulyasa. E. (2018). Manajemen Pendidikan Karakter. Jakarta: Bumi Aksara.

Nasirudin, Mohammad. 2010. Pendidikan Tasawuf. Semarang: RaSAIL Group.

Referensi.data.kemendikbud.go.id/index11.php ?kode $=030805 \&$ level $=3$ diunduh pada 12 Mei 2020.

Trianto. 2010. Model Pembelajaran Terpadu. Jakarta: Bumi Aksara.

Undang-Undang Nomor 20 Tahun 2003 tentang Sistem Pendidikan Nasional pasal 3.

Wibowo, Agus. 2012. Pendidikan Karakter: Strategi Membangun Karakter Bangsa Berperadaban. Yogyakarta: Pustaka Pelajar. 